\title{
Hubungan Bersyukur dengan Kesejahteraan Subjektif pada Orang Tua yang Memiliki Anak Tunagrahita di SLB Negeri 2 Kota Padang
}

\author{
Murisal, Trisna Hasanah \\ Universitas Islam Negeri Imam Bonjol Padang
}

Diterima: Juni 2017. Disetujui: Oktober 2017. Dipublikasikan: Desember 2017

\begin{abstract}
This study aims to determine the relationship between gratitude with subjective well-being in parents who have children tunagrahita in SLB Negeri 2 Padang. Measuring tool in this research is a psychology scale that reveal aspects of research in the form of statement aitem. Data were collected using two scales, namely the grateful scale and the subjects' welfare scale. The grateful scale is referenced from Al-Ghazali's theory whose operations are based on the interpretation of the verses on gratitude. While the subjective well-being scale is referenced from the diener theory which states that subjective well being consists of two dimensions, namely affective and cognitive. Subjects in this study were parents who have children in school Tunagrahita SLB Negeri 2 Padang amounted to 83 people. The data retrieval technique in this research is using simple random sampling which means that each subject has equal chance to be selected. The result of correlation analysis shows the relationship between gratitude with subjective well-being in the parents who have children tunagrahita in SLB Negeri 2 Padang. The correlation coefficient from the result of data analysis is $0,156(r x y=0,516 p<0,05)$. The general description of the research data shows that the grateful level of the parents of the child with the tunagrahita is included in the high criterion with the percentage of 56\% and the subjective subjective well-being of the child's parents with a tunagrahita of $62 \%$. This means that the parent of the child is able to be enthusiastic in educating his child and accepting the child's circumstances graciously.
\end{abstract}

Keywords : Behavior; Student; discipline; divorce

Abstrak: Penelitian ini bertujuan untuk mengetahui adanya hubungan antara bersyukur dengan kesejahteraan subjektif pada orang tua yang memiliki anak tunagrahita di SLB Negeri 2 Padang. Alat ukur dalam penelitian ini adalah berupa skala psikologi yang mengungkap aspek-aspek penelitian berupa aitem- aitem pernyataan. Data dikumpulkan dengan menggunakan dua skala, yaitu skala bersyukur dan skala kesejahteraan subjekif. Skala bersyukur dirujuk dari teori Al- Ghazali yang operasionalisasinya berdasarkan tafsir dari ayat-ayat mengenai syukur. Sedangkan skala kesejahteraan subjektif dirujuk dari teori diener yang menyatakan bahwa kesejahteraan subjektif terdiri dari dua dimensi, yaitu afektif dan kognitif. Subjek dalam penelitian ini adalah orang tua yang memiliki anak tunagrahita di SLB Negeri 2 Padang yang berjumlah 83 orang. Teknik pengambilan data dalam penelitian ini adalah menggunakan simple random sampling yang berarti bahwa setiap subjek memiliki peluang yang sama untuk dipilih. Hasil analisis korelasi menunjukkan adanya hubungan antara bersyukur dengan kesejahteraan subjektif pada orang tua yang memiliki anak tunagrahita di SLB Negeri 2 Padang. Koefisien korelasi dari hasil analisis data adalah sebesar 0,156 ( $\mathrm{rxy}=0,516 \mathrm{p}<0,05)$. Deskripsi umum dari data penelitian menunjukkan bahwa tingkat bersyukur orang tua anak tunagrahita termasuk ke dalam kriteria tinggi dengan persentase sebesar $56 \%$ dan tingginya kesejahteraan subjektif orang tua anak tunagrahita sebesar $62 \%$. Hal ini berarti bahwa orang tua anak tunagrahita mampu bersemangat dalam mendidik anaknya dan menerima keadaan anaknya dengan lapang dada.

Kata Kunci : Behavior; Indisipliner; siswa; perceraian

\section{Pendahuluan}

Anak merupakan anugerah yang diberikan oleh Allah SWT sebagai pelengkap kebahagiaan keluarga dan tercapainya tujuan berumah tangga. Setiap orang tua idealnya menginginkan anak yang terlahir sempurna. Akan tetapi kenyataannya tidak semua anak yang terlahir normal, ada anak yang terlahir dengan kebutuhan khusus yang membutuhkan pengasuhan dan pendidikan khusus. Anak dengan karakteristik seperti ini disebut dengan Anak Berkebutuhan Khusus (ABK). 
Definisikan ABK sebagai anak yang menyimpang dari rata-rata anak normal dalam hal: ciri-ciri mental, kemampuan-kemampuan sensorik, fisik dan neuromuskular, perilaku sosial dan emosional, kemampuan berkomunikasi maupun kombinasi dua atau lebih dari hal-hal di atas; sejauh mana ia memerlukan modifikasi dari tugas-tugas sekolah, metode belajar atau pelayanan terkait lainnya, yang ditujukan untuk mengembangkan potensi atau kapasitasnya secara maksimal (Mangunsong, 2009). (Hallahan \& Kauffman, 2006) Mendefinisikan anak berkebutuhan khusus (ABK) adalah anak-anak yang membutuhkan pendidikan dan pelayanan khusus untuk mengembangkan segenap potensi yang mereka miliki.

Berdasarkan UU No.20 tahun 2003 pasal 32 ayat 1 disebutkan bahwa pendidikan khusus merupakan pendidikan bagi peserta didik yang memiliki tingkat kesulitan dalam mengikuti proses pembelajaran karena kelainan fisik, emosional, mental, sosial, atau memiliki potensi kecerdasan dan bakat istimewa. ABK memiliki hak yang sama seperti anak-anak pada umumnya. Berdasarkan UU No.8 tahun 2016 pasal 5 ayat 3 tentang hak penyandang disabilitas disebutkan bahwa ABK mempunyai hak untuk perawatan dan pengasuhan keluarga atau keluarga pengganti untuk tumbuh kembang secara optimal. Dalam hal ini, orang tua mempunyai peranan yang penting sebagai salah satu anggota keluarga ABK, karena orang tua merupakan interaksi sosial pertama yang akan membentuk kepribadian anak.

Peraturan menteri No.70 tahun 2009 mengklarifikasikan ABK dengan lebih rinci yaitu tunanetra, tunarungu, berkesulitan belajar, lamban belajar, autis, memiliki gangguan motorik, menjadi korban penyalahgunaan narkoba, tunaganda, dan memiliki kelainan lainnya.

Dalam masing-masing kekhususan ABK yang telah disebutkan diatas peneliti tertarik untuk meneliti lebih lanjut mengenai anak tunagrahita. Karena berdasarkan pengambilan data awal yang peneliti lakukan pada Rabu(14/12/16) di SLB Negeri 2 Padang terdapat 83 orang ABK dengan kekhususan tunagrahita. Anak tunagrahita yang terdapat di SLB Negeri 2 Padang berjumlah 83 orang dari total jumlah siswa SLB sebanyak 108. Berarti dari 108 siswa SLB ada 77\% anak tunagrahita di SLB Negeri 2 Kota Padang.

Tunagrahita merupakan kata lain dari retardasi mental yang berarti keterbelakangan mental. Tunagrahita adalah kelainan pada pertumbuhan dan perkembangan pada mental intelektual (mental retardasi) sejak bayi atau dalam kandungan dan anak-anak yang disebabkan oleh faktor organik biologis maupun faktor fungsional, adakalanya disertai dengan cacat fisik. Anak tunagrahita memiliki tingkat kemandirian yang rendah sehingga membutuhkan perhatian dan bimbingan orang tua secara khusus agar anak tunagrahita dapat terlatih dalam mengurus dirinya sendiri.

Kesejahteraan subjektif merupakan evaluasi seseorang terhadap hidupnya secara kognitif dan afektif. Secara kognitif kesejahteraan subjektif pada diri seseorang dapat diindikasikan dengan merasakan kepuasan hidup setelah memikirkan dan mengevaluasi pengalaman- pengalaman pada masa lalu(Deiner, Lucas, \& Oishi, 2002). Secara afektif, kesejahteraan subjektif yang dialami oleh seseorang dapat diindikasikan dengan afek positif dan afek negatif. Individu yang mengalami afek positif biasanya memiliki ciri-ciri yaitu gembira, mempunyai semangat yang baik, terlihat sangat bahagia, tenang dan penu(Snyder \& Lopex, 2002)h kedamaian, merasa puas, dan totalitas dalam menjalani kehidupannya. Sedangkan individu yang memiliki afek negatif memiliki indikasi sikap tidak memiliki kegembiraan, gelisah, tidak nyaman, tidak memiliki harapan, tidak berusaha untuk mewujudkan impian, merasa tidak berharga(Snyder \& Lopex, 2002).

Kepuasan hidup merupakan kesejahteraan yang timbul karena tercapainya tujuan yang diinginkan. Namun pada kenyataannya, tujuan yang ingin dicapai oleh individu terkadang tidak 
sesuai dengan apa yang ia dapatkan sehingga menimbulkan afek negatif. Wawancara yang dilakukan pada Senin (01/11/16) di SLB Negeri 2 Padang terhadap salah satu orang tua anak tunagrahita berinisial $\mathrm{S}$ mengatakan bahwa :

"D merupakan anak saya satu- satunya karena kakaknya sudah meninggal. Anak saya ini memiliki gangguan tunagrahita. Saya sebenarnya kaget dengan keadaan D yang seperti ini, dia merupakan harapan satu-satunya saya dan istri yang akan membuat saya bangga dengan prestasi dan capaian- capaiannya namun ternyata D mempunyai kelainan. Saya sejak D TK mengurus D secara intens bersama istri, ya beginilah, kami harus bersabar. Karena jika tidak bersabar maka akan terjadi pertengkaran antara saya dan istri akibat emosi karena kewalahan mendidik D. D ini tidak mau diam anaknya, kerjanya berjalan saja terus kalau dibawa kemana-mana, sangat kewalahan saya rasanya namun karena D anak saya juga maka saya mempunyai kewajiban untuk merawatnya walaupun dengan keterbatasan seperti ini, karena menurut saya banyak orang yang lebih susah hidupnya daripada saya sehingga dengan mengingat itu saya mampu bersyukur". (Wawancara pada Senin, 01 November 2016 pada Pukul 07.30 s.d 07.45 WIB). Kemudian salah satu orang tua anak tunagrahita berinisial $Y$ juga mengatakan bahwa :

"Anak saya memiliki gangguan tunagrahita sedang menurut diagnosa dokter, padahal ketika anak saya masih bayi sampai balita dia terlihat normal. Saya sangat shock ketika menerima hasil asesment mengenai gangguan yang dialami oleh anak saya, sehingga saya dan ayahnya kebingungan bagaimana caranya mengasuh dan merawat anak saya ini. Kebingungan itu yang kadang membuat saya menjadi sering emosi dan marah- marah, namun setelah terbiasa dengan keadaan seperti ini akhirnya saya bisa mengerti bagaimana cara mendidik anak saya ini. Saya cukup bersyukur karena dengan Allah memberikan saya ujian seperti ini saya mampu mengetahui banyak hal khususnya mengenai ABK". (Wawancara pada Senin, 01 November 2016 pada Pukul 08.00 s.d 08.32 WIB).

Hasil wawancara pada Rabu (14/12/16) dengan orang tua ABK yang anaknya memiliki kekhususan dalam tunagrahita di SLB Negeri 2 Padang mengatakan bahwa :

"Anak saya ini susah sekali untuk mandiri, bahkan untuk mandi saja saya masih perlu mengajari dan membimbing agar bisa mandi dengan bersih, padahal anak saya ininberusia 10 tahun, seharusnya sudah bisa mengatur dirinya sendiri. Tapi saya harus banyak bersabar karena ini anak saya juga, dan saya harus bersyukur, karena dengan bersyukur saya bisa menerima keadaan anak saya dan kehidupan saya seperti ini" (Wawancara pada Rabu, 14 Desember 2016 pukul 10.00 s.d 10.12 WIB).

Bersyukur merupakan perwujudan dari rasa sabar dan kasih sayang terhadap seseorang atau sesuatu yang menyebabkan terciptanya kesejahteraan subjektif. Penelitian yang dilakukan oleh Rohmah (2013) menyatakan bahwa salah satu faktor yang menyebabkan tingginya kualitas hidup ibu dengan anak yang memiliki gangguan spektrum austitik ini adalah optimisme yang tinggi. Pada awalnya ibu tidak menerima keadaan anaknya dengan gangguan spektrum austistik, namun karena dukungan sosial, dukungan keluarga, dan optimisme yang tinggi mampu membuat ibu menerima keadaan anaknya dan kemudian merawat anaknya dengan baik. Optimisme yang tinggi akan mendorong seseorang dalam kesejahteraan subjektif yang menentukan kualitas hidup seseorang. Dari hasil penelitian ini disimpulkan bahwa menjadi orang tua, khususnya menjadi ibu bukanlah suatu pekerjaan yang mudah, karena untuk menjalankan peran sebagai ibu harus memiliki rasa sabar dan kasih sayang yang tinggi terhadap anaknya. 
Bersyukur (gratitude) dapat diartikan sebagai keadaan dalam diri seseorang untuk mengapresiasi segala peristiwa yang terjadi dalam kehidupan sehari-hari dan atas pengalamanpengalamannya(Snyder \& Lopex, 2002). Sedangkan menurut Ibnu Ujaibah (Hambali, 2015), syukur merupakan kebahagiaan hati atas nikmat yang diperoleh yang diikuti dengan pengarahan seluruh anggota tubuh supaya taat kepada Sang Pemberi nikmat serta pengakuan atas segala nikmat yang diberi-Nya dengan rendah hati. Jadi, bersyukur merupakan keadaan dalam diri seseorang untuk menerima segala peristiwa yang terjadi dan mengakui segala nikmat yang diberi-Nya dengan melakukan segala sesuatu yang dicintai oleh-Nya.

Fordyce $(1997,1983)$ menyatakan bahwa bersyukur merupakan salah satu faktor yang menyebabkan meningkatnya kesejahteraan subjektif pada diri seseorang karena dengan bersyukur seseorang mampu melakukan berbagai kegiatan sosial yang mampu membantu orang lain (Snyder. 2002:328). Perilaku membantu orang lain merupakan perwujudan rasa syukur yang mampu menciptakan kesejahteraan subjektif pada diri individu.

Berdasarkan pembahasan di atas, dikemukakan bahwa kesejahteraan subjektif sangat dibutuhkan untuk orang tua, terutama pada orang tua yang memiliki anak berkebutuhan khusus dengan kekhususan tunagrahita. Dari hal tersebut peneliti tertarik untuk mengetahui "Hubungan Bersyukur (Gratitude) dengan Kesejahteraan Subjektif (Subjective Well Being) pada Orang Tua yang Memiliki Anak Tunagrahita di SLB Negeri 2 Kota Padang”.

\section{Metode Penelitian}

Metode penelitian yang digunakan dalam penelitian ini adalah metode kuantitatif. Teknik pengambilan data yang digunakan dalam penelitian ini adalah simple random sampling. Simple random sampling maksudnya adalah cara penarikan sampel secara acak sederhana yang menyebabkan setiap subjek memiliki peluang yang sama untuk dipilih.

Alat ukur dalam penelitian ini menggunakan skala bersyukur yang dirujuk dari teori AlGhazali dan skala kesejahteraan subjektif yang dirujuk dari teori Diener. Besarnya sampel dalam penelitian ini adalah 83 orang dari 107 orang tua anak tunagrahita di SLB Negeri 2 Padang.

Pengujian hipotesis menggunakan teknik analisis korelasi pearson product moment dengan dibantu aplikasi SPSS Versi 16 For windows.

\section{Hasil dan Pembahasan}

Analisis data yang diperoleh menunjukkan bahwa dari 83 orang subjek yang diteliti, hanya 37 orang yang memiliki tingkat bersyukur yang rendah, sedangkan 56 orang subjek memiliki tingkat bersyukur yang tinggi. Maka dari itu dapat dijelaskan orang tua yang memiliki anak tunagrahita di SLB Negeri Padang memiliki tingkat bersyukur yang tinggi.

Orang tua anak tunagrahita yang bersyukur memiliki indikasi dalam bentuk perilaku sehari-hari, hal ini dapat dilihat dari nilai kebersyukuran itu sendiri. Orang tua anak tunagrahita yang memiliki tingkat bersyukur tinggi cenderung menggunakan semua yang dimilikinya untuk perilaku-perilaku positif seperti berusaha mempersiapkan pendidikan yang baik untuk anaknya, mendidik anak sesuai tuntunan islam dan pola asuh yang sesuai dengan kebutuhan anak. Selain itu, orang tua anak tunagrahita yang memiliki tingkat bersyukur tinggi juga menyadari bahwa segala yang terjadi dalam kehidupannya merupakan anugerah dari Allah.

Kemudian dari analisis data terhadap kesejahteraan subjektif subjek, terdapat 32 orang yang memiliki tingkat kesejahteraan subjektif yang rendah, sedangkan 51 orang subjek memiliki tingkat kesejahteraan subjek yang tinggi. Dari analisis data tersebut dapat 
diketahui bahwa orang tua yang memiliki anak tunagrahita di SLB Negeri 2 Padang cenderung memiliki kesejahteraan subjektif yang tinggi.

Dalam kamus istilah agama, dijelaskan bahwa syukur adalah berterima kasih, yaitu merasa gembira dan puas serta berterima kasih atas segala rahmat dan nikmat- Nya yang dilimpahkan kepadanya, sungguhpun tidak sesuai dengan yang diharapkan seumpamanya (Shodiq, 2000:328). Adapun Sa'id Hawwa (2007:381) menyatakan bahwa bersyukur merupakan mengerahkan secara total apa yang dimilikinya dan melakukan apa yang dicintai Allah SWT. Menurut Ubaid (2014:171-173) syukur adalah memuji Dzat yang memberi kenikmatan atas limpahan kebaikan yang Dia anugerahkan.

Emmons (Emmons, 2005) juga berpendapat bahwa syukur diartikan sebagai gratitude yang berarti pengalaman seseorang tentang sesuatu yang berharga dari orang lain yang ditandai dengan menghargai orang lain, penerimaan yang berharga, menolong sebagai balasan atas kebaikan orang lain. Bersyukur dapat diartikan sebagai keadaan dalam diri seseorang untuk mengapresiasi segala peristiwa yang terjadi dalam kehidupan sehari-hari dan atas pengalamanpengalamannya(Snyder \& Lopex, 2002). Hal ini senada dengan ungkapan Sa'id Hawwa dalam bukunya "Tazkiyatunnafs" yang menyatakan salah satu jalan syukur adalah dengan bertakwa. Bertakwa merupakan melaksanakan kebaikan-kebaikan kepada orang lain serta menjauhi apaapa yang dilarang oleh Allah.

Menurut Al-Ghazali (2013:66-75) syukur terdiri dari batasan-batasan sikap yang berarti merupakan perwujudan dari rasa syukur itu sendiri yakni bersyukur. Bersyukur merupakan sikap dari rasa syukur yang terwujud dalam akhlak (perilaku) kepada sesama dan akhlak kepada Allah. Batasan sikap syukur tersebut ada tiga yaitu tersusun dari ilmu, hal ihwal, dan amal perbuatan. Ilmu adalah pokok, lalu mewariskan hal ihwal, dan amal perbuatan. Batasan sikap syukur ini yang penulis konstruk menjadi sebuah alat ukur psikologi untuk meneliti tingkat bersyukur orang tua yang memiliki anak tunagrahita di SLB Negeri 2 Padang.

Maka dapat penulis jelaskan bahwa untuk mewujudkan rasa syukur sebagai interpretasi dari apreasiasi yang ada dalam diri seseorang maka seseorang yang bersyukur harus mengetahui tentang kenikmatan yang diperoleh serta Dzat ataupun orang yang memberi kenikmatan, lalu dari hal itu akan timbul rasa gembira/senang atas kenikmatan yang diterima serta menimbulkan rasa apresiasi terhadap yang memberi kenikmatan dan dorongan untuk berbuat kebaikan kepada sesama sebagai wujud dari rasa syukur tersebut. Hal itu dinamakan dengan syukur amal perbuatan yang terdiri dari lisan, anggota badan, dan hati. Senada dengan penjelasan diatas, Fitzgerald (1988) juga mengidentifikasikan syukur ke dalam beberapa komponen, yaitu apresiasi yang hangat atas sesuatu atau seseorang, kehendak untuk berbuat baik kepada seseorang atau sesuatu, sikap yang positif diikuti dengan niat baik terhadap orang lain. Maka dari penjelasan di atas dapat diketahui bahwa bersyukur merupakan perwujudan rasa syukur yang ditunjukkan dengan sikap yang baik kepada orang lain sebagai apresiasi yang muncul dari dalam diri seseorang.

Bersyukur merupakan perasaan puas dan gembira atas segala yang diterima. Hamka (2015:90) dalam tafsir al-azhar edisi revisi menjelaskan bahwa berdasarkan makna surat Ibrahim ayat ke-7 bahwa orang-orang yang bersyukur memiliki kelapangan hati dan kebahagiaan yang ditandai dengan menerima segala yang ditetapkan oleh Allah SWT sehingga Allah SWT mampu menambah nikmat-Nya. Timbulnya kufur (tidak bersyukur) yaitu rasa tidak puas, rasa tidak mengenal terima kasih, dan menghitung sesuatu dari segi kekurangannya saja adalah siksa bagi jiwa itu sendiri. 
Snyder (2002) menjelaskan bahwa kesejahteraan subjektif pada diri seseorang diindikasikan dengan pemaknaan seseorang terhadap kebahagiaan yang dimilikinya. Ketika seseorang mampu memaknai kehidupannya dengan baik maka seseorang tersebut akan sejahtera, sejahtera secara subjektif dapat diwujudkan dengan bersyukur atas nikmat yang Allah berikan kepada individu tersebut.

Menurut Diener dkk mendefinisikan kesejahteraan subjektif sebagai evaluasi seseorang terhadap hidupnya secara kognitif maupun afektif, evaluasi ini menghasilkan reaksi emosional yang baik atas setiap peristiwa yang dialami dan respond kognitif seseorang yang menghasilkan kepuasan hidup dan perasaan berharga. Kesejahteraan subjektif ditandai dengan pengalaman- pengalaman positif seseorang, rendahnya mood negatif, dan tingginya kepuasan hidup(Snyder \& Lopex, 2002).

Kesejahteraan subjektif juga disebut sebagai sinonim dari kebahagiaan. Diener (2002) mendefinisikan kesejahteraan subjektif sebagai kombinasi dari afek positif (yang didalamnya tidak terdapat afek negatif) dan kepuasan hidup. Kesejahteraan subjektif didefinisikan sebagai evaluasi seseorang terhadap hidupnya secara kognitif maupun afektif. Secara kognitif seseorang akan mengalami kepuasan hidup atas pengalaman- pengalaman positif dalam hidup dan secara afektif akan merasakan afek positif dan negatif (Deiner et al., 2002).

Watson (2002) berpendapat bahwa antara afek negatif dan afek positif mempunyai sisi independen yang tidak saling mempengaruhi, karena seseorang yang mempunyai kesejahteraan subjektif yang tinggi bisa dalam waktu bersamaan mengalami afek negatif seperti merasa marah, merasa cemas, merasa tertekan, merasa gugup dan merasa bersalah kepada orang lain. Dalam penelitiannya Watson (2002) menemukan bahwa adanya hubungan antara afek negatif dengan perasaan nyaman, kenyamanan diri, dan penuh perhatian. Maka dapat dijelaskan bahwa seseorang yang merasa sejahtera secara afektif bisa ditinjau dari afek positif dan afek negatif. Karena kesejahteraan subjektif seseorang tidak hanya ditentukan oleh kepuasan hidup, akan tetapi akan adanya afek negatif dan afek positif. Karena sejahtera secara subjektif merupakan penilaian dari diri individu itu sendiri terhadap hidupnya tanpa adanya intervensi ataupun penilaian dari orang lain.

Adina Pramitasari (2016) dalam penelitiannya mengenai hubungan kebersyukuran dengan kesejahteraan subjektif menjelaskan bahwa seseorang yang mempunyai kesejahteraan subjektif yang tinggi disebabkan oleh adanya rasa kebersyukuran yang tinggi dari dalam dirinya sehingga menghasilkan respon positif terhadap sesuatu yang diterima dalam kehidupannya. Banyak beban hidup yang menyebabkan stress akan berkurang dengan rasa syukur yang tinggi(Pramitasari, 2016).

Dewanto \& Retnowati (2015) melakukan penelitian tentang intervensi kebersyukuran untuk meningkatkan kesejahteraan penyandang disabilitas fisik. Dari hasil penelitiannya dapat diambil kesimpulan bahwa bersyukur merupakan faktor yang saling berpengaruh terhadap kesejahteraan seseorang. Orang yang memiliki disabilitas fisik sulit untuk menyesuaikan diri dalam pergaulan sehari-hari karena keterbatasan fisiknya, hal ini bisa menjadi salah satu sumber ketidaknyamanan dalam dirinya. Akan tetapi setelah mengalami fase kehidupan seseorang tersebut mampu bersyukur yang menyebabkannya untuk sejahtera(Dewanto \& Retnowati, 2015).

Dari dua penelitian di atas dapat dijelaskan, Bersyukur merupakan salah faktor yang dapat menyebabkan terciptanya rasa sejahtera dalam kehidupan seseorang yang diartikan sebagai kesejahteraan subjektif. Apapun stressor yang melanda seseorang akan dapat diatasi dan dihadapi dengan bersyukur. Termasuk stressor yang dihadapi orang tua anak tunagrahita. Menurut penelitian yang dilakukan oleh Bima Adi Prasa (2012) menyatakan bahwa orang tua yang 
memiliki anak tunagrahita memiliki coping stress dari luar maupun dari dalam yang terdiri dari dukungan sosial, keyakinan diri, penghargaan diri, dan menerima tanggung jawab(Prasa, 2012).

Maka dari penjelasan di atas dapat disimpulkan semakin tinggi tingkat bersyukur seseorang akan semakin tinggi juga tingkat kesejahteraan subjektif seseorang tersebut. Hasil penelitian yang didapatkan dari olahan data seperti yang dipaparkan di atas sejalan dengan hipotesis penulis di Bab II karena adanya hubungan antara bersyukur dengan kesejahteraan subjektif pada orang tua yang memiliki anak tunagrahita di SLB Negeri 2 Padang. Terdapatnya hubungan positif yang signifikan antara bersyukur dan kesejahteraan subjektif subjek dapat dilihat dari taraf signifikansi linieritasnya yaitu 0,000 yang berarti lebih kecil dari 0,05 . Hal ini menjelaskan bahwa antara bersyukur dan kesejahteraan subjektif memiliki hubungan linier yang signifikan. Selain itu, dapat dilihat dari koefisien korelasi dari penelitian penulis yaitu sebesar 0,516. Periantalo (2016:186) menjelaskan bahwa kisaran 0,41 s.d 0,60 memiliki kekuatan korelasi yang sedang. Maka dapat disimpulkan bahwa bersyukur dengan kesejahteraan subjektif pada orang tua yang memiliki anak tunagrahita di SLB Negeri 2 Padang memiliki hubungan positif yang siginifikan dengan taraf signifikansi sebesar $0,000(\mathrm{p}<0,05)$ dan koefisien korelasi sebesar 0,516 ( $\mathrm{rxy}=0,516)$.

Hubungan yang positif antara bersyukur dengan kesejahteraan subjektif tersebut menjelaskan bahwa orang tua anak tunagrahita dapat bersyukur dengan mengetahui semua pengampunan dan kemudahan dari Allah. Hal ini dijelaskan melalui perilaku orang tua yang semakin bersemangat dalam mendidik anak tunagrahita. Perasaan bersemangat merupakan salah satu ciri-ciri seseorang mengalami afek positif yang merupakan bagian dari kesejahteraan subjektif. Semakin orang tua anak tunagrahita merasa bersemangat maka hal tersebut akan menimbulkan sikap syukur yang tinggi. Sikap syukur atau bersyukur yang tinggi ditandai dengan berperilaku positif atau perilaku yang menambah pahala di sisi Allah. Perilaku yang menambah pahala di sisi Allah tersebut seperti mengucapkan lafadz Allah dalam setiap kegiatan, bersedekah di waktu lapang, mengantarkan anak ke sekolah, mendidik anak dengan cara yang baik sesuai tuntunan islam, mengajarkan anak cara berperilaku yang baik seperti membantu orang lain, mendahulukan kepentingan orang lain.

\section{Simpulan dan Saran}

Dari hasil dan pembahasan dapat disimpulkan bahawa dari deskripsi umum dari data penelitian menunjukkan bahwa tingkat bersyukur orang tua anak tunagrahita termasuk ke dalam kriteria tinggi dengan persentase sebesar $56 \%$ dan tingginya kesejahteraan subjektif orang tua anak tunagrahita sebesar 62\%. Hal ini berarti bahwa orang tua anak tunagrahita mampu bersemangat dalam mendidik anaknya dan menerima keadaan anaknya dengan lapang dada.

\section{Daftar Pustaka}

Deiner, E., Lucas, R. E., \& Oishi, S. (2002). Subjective Well-Being: The Science of Happiness and Life Satisfaction. In C. . Snyder \& S. J. Lopex (Eds.), Handbook of positive psychology (p. 63). New York: Oxfort University Press. https://doi.org/0-19-513533-4

Dewanto, W., \& Retnowati, S. (2015). Intervensi Kebersyukuran dan Kesejahteraan Penyandang Disabilitas Fisik. Gadjah Mada Journal of Professional Psychology, 1(1), 3347. Retrieved from https://jurnal.ugm.ac.id/gamajpp/article/view/7359

Emmons, R. A. (2005). Striving for the sacred: Personal goals, life meaning, and religion. Journal of Social Issues, 61(4), 731-745. https://doi.org/10.1111/j.1540-4560.2005.00429.x 
Hallahan, D. P., \& Kauffman, J. M. (2006). Exceptional learners: introduction to special education (10th ed.). Pearson/A and B.

Mangunsong, F. (2009). Psikologi dan pendidikan anak berkebutuhan khusus. LPSP3 UI.

Pramitasari, A. (2016). Hubungan Kebersyukuran dengan Kesejahteraan Subjektif pada Guru SMA Negeri I Sewon. UIN Sunan Kalijaga.

Prasa, B. A. (2012). Stres dan Koping Orangtua dengan Anak Retardasi Mental. Psikologi Klinis, 1(9), 1-20.

Snyder, C. ., \& Lopex, S. J. (2002). Handbook of Positive Psychology. In Handbook of positive psychology (pp. 120-134). https://doi.org/10.1093/oxfordhb/9780195187243.001.0001 